1975

\title{
An Archaeological Survey of Tributary Channel to Aransas Pass, Texas
}

Kenyon L. McDonald

Follow this and additional works at: https://scholarworks.sfasu.edu/ita

Part of the American Material Culture Commons, Archaeological Anthropology Commons, Environmental Studies Commons, Other American Studies Commons, Other Arts and Humanities Commons, Other History of Art, Architecture, and Archaeology Commons, and the United States History Commons

Tell us how this article helped you.

This Article is brought to you for free and open access by the Center for Regional Heritage Research at SFA ScholarWorks. It has been accepted for inclusion in Index of Texas Archaeology: Open Access Gray Literature from the Lone Star State by an authorized editor of SFA ScholarWorks. For more information, please contact cdsscholarworks@sfasu.edu. 


\section{An Archaeological Survey of Tributary Channel to Aransas Pass, Texas \\ Creative Commons License \\ (c) (i) (8)}

This work is licensed under a Creative Commons Attribution-NonCommercial 4.0 International License 


\section{AN ARCHAEOLOGICAL SURVEY OF TRIBUTARY \\ CHANNEL TO ARANSAS PASS, TEXAS}

Kenyon I. McDonald

Center for Archaeological Research The University of Texas at San Antonio Archaeological Survey Report, No. 13.

1975 


\section{TABLE OF CONTENTS}

$\begin{array}{lc} & \text { Page } \\ \text { Introduction } & 1 \\ \text { Review of the Archaeology in the Project Area } & 2 \\ \text { Methodology and Procedures } & 4 \\ \text { Results of the Survey } & 5 \\ \text { Summary } & 6 \\ \text { Feconnendations } & 7 \\ \text { Bibliography } & 8\end{array}$




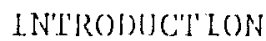

In early August, 1975, the Center for Archaeological Research at The University of Texas at San Antonio, carried out an appraisal of archaeological and historical resources in certain areas along the Gulf Intracoastal Waterway Tributary Channel to Aransas Pass, Texas. The work was done under the terms of a contract (DACN64-76-M-0040) between The University of Texas at San Antonio and the U. S. Army Corps of Engineers, Galveston District.

The Corps of Engineers proposes to modify the present tributary channel to Aransas Pass through a program of dredging which will both widen and deepen the channel in Nueces and San Patricio Countjes. As a result of the proposed dredging operations, several areas adjacent to the tributary channel will be affected by the disposal of dredged material.

Therefore, the investigations by the Center were designed to determine if archaeological and/or historical resources existed within those areas which were to be affected. In accordance with corps of Engineers specifications, the Center had the further responsibilities of evaluating the significance and importance of such resources, of ascertaining the potential effects of dredging and disposal activities on the resources, and of recommending means of mitigating damage or destruction of such resources.

The specific survey areas consisted of six localities, each of which may be utilized for spoil disposal. These were: (1) an area of 120 acres on the northwest portion of South Harbor Island, adjacent 
to a private channel; (2) 95 acres near, and southwest of, Texas Highway 361 on. central South llarbor Island; (3) 120 acres on North Harbor Island, adjacent to the Lydia Ann Channel; (4) an area of 35 acres just east of Aransas Pass and adjacent to the Conn Brown Harbor Turning Basin; (5) 75 acres east of Aransas Pass, between Redfish Bay and the Gulf Intracoastal Waterway and north of Texas Highway 361; and (6) 60 acres on and adjacent to Stedman Island, and south of Texas Ilighway 361. In all, a total of 505 acres was surveyed.

Generally speaking, all of the survey areas (with the exception of North Harbor Island, as described below), can be described as part of the coastal lowlands and bay tidal flats ecosystems (biotopes included here are mudflats, grassflats, saltwater marshes, and spoil banks). Rarely do these locales exceed five feet in height above sea level. The vegetation consists (or consisted) mostly of various tidal and lowland grasses and shrubs, such as saltgrass (Distichlis spicata) and saltbrush (Atriplex klebergorum). Additional descriptions of the area's biota can be found in Blair (1950).

The North Harbor Island locality differs significantly from the other survey areas in that it consists largely of high sand dunes, ranging from 10 to 25 feet above sea level. The vegetation here is much more varied, with the island being drier and at a higher elevation than the other localities under study.

REVIEW OF THE ARCHAEOLOGY IN THE PROJECT AREA Archaeological investigations on this part of the Texas coast have revealed a long cultural sequence for aboriginal populations. 
The earliest evidence of human existence dates from Palco-Indian times, approximately 9200 - 6000 B.C. The cultural remnants from this period include fluted projectile points. There was apparently much more human utilization of the coastal zone in the period of 6000 B.C. to A.D. 1200, a time span known as the Archaic in archaeological terminology. The cultural manifestations of the Archaic in the survey area are grouped in the "Aransas Phase". It apparently began around 2000/3000 B.C. and lasted until A.D. 1200 when a different cultural unit, the "Rockport Phase" is noted. The "Aransas Phase" is well documented from sites on the Live Dak Peninsula (Campbel1 1947, 1952; Corbin 1963; Story 1968). James Corbin (1974) also gives a summary of the areas "Aransas Phase".

The Late Prehistoric "Rockport Phase" (A.D. 1200 to Historic times) is characterized by the appearance of the bow and arrow and the manufacturing of pottery. These and other traits constitute a cultural pattern distinct from the earlier "Aransas Phase".

There is now a large body of information on archaeology of the central Texas coast. Summaries can be found in suhm et al. (1.954), Campbell (1958a) and Briggs (1971); bibliographies of published data are found in Campbell (1958b) and Hester (1974). Many references were made of this information and are listed at the end of this report. Much of the archaeological research near the survey area was conducted in the late 1950's and early 1960's by James F. Corbin. Many of his sites and others are found in the area just west of $\Lambda$ ransas Pass (towards Portland) along the bay shore and in the interior. Other published surveys of the region adjacent to the survey area 
include Dibble (1972), Dillehay (1973), McDonald and Dibble (1973). T. R. Hester has also worked in the area in recent months, carrying out a study for Southwest Research Institute.

The closest recorded site near the survey area is 41 SP 72 . This site is located approximately one mile southwest of the point where Ransome Island crosses the Intracoastal Vaterway, one and onefourth miles west of the north end of Ransome Island. The location of this site is approximately one and one-fourth miles from the Conn Brown Turning Basin in Aransas Pass.

Two burial sites, 41 SP 64 and 41 SP 78, are located approximately three miles southwest of Aransas Pass (IIester and Corbin 1975). Site 41 SP 64 may be classified as belonging to the Rockport Phase and may possibly (because of stemmed dart point collected there) go as far back as the Aransas period. 41 SP 78 cannot be dated at the present time. These two sites provided some important information, but they have been totally destroyed by construction.

\section{METTIODOLOGY AND PROCEDURES}

Prior to initiating field work in the area, time was spent in a general review of published archaeological data pertinent to the locality, much of which is summarized in the preceding section. Much assistance was given in this regard by Dr. Thomas R. llester, Director of the Center for Archaeological Research.

In the period of August 1 to August 5, 1975, intensive field inspection of the areas proposed for modification was conducted by the author. Survey was conducted both on foot and by boat, the latter being needed to reach certain localities. All areas slated for 
modification were thoroughly investigated.

RESULTS OF THE SURVEY

An extensive and careful examination of all six localities cited above revealed no surficial evidence of aboriginal or historical remains. It was apparent that all of these localities have been disturbed or altered in recent times, or have, in the past, been utilized for the dumping of dredged material.

The area in the vicinity of the Conn Brown Harbor Turning Basin has been extensively modified by construction. At present, most of this area is covered by a roadway and an asphalt parking lot; portions seem to have been used at an earlier date for spoil disposal. The area directly adjacent to and south of the turning basin (and across the Gulf Intracoastal Waterway) appears also to have been a spoil dumping site. This 75-acre area is surrounded by a five-foot high wall with the enclosed area resembling a low basin, frequently under water as a result of bay seepage.

The survey area on Stedman Island is a low-lying locality, generally less than three feet above sea level. It is almost completely covered by coastal grasses. Oil storage tanks and maintenance roads are present. No archaeological or historical evidence was found. Two other localities (95 acres on central South Harbor Island and 120 acres adjacent on northwest South Harbor Island) west of the tributary channel to Aransas Pass are also very low, less than three feet above sea level. They, too, are covered with coastal grasses and shrubs. There are oil industry maintenance roads, evidence of road construction, and the scars of recent bulldozing in these two 
areas. No cultural resources were located.

North Harbor Island appeared upon first inspection to have the greatest potential for yielding evidence of aboriginal utilization. It is relatively high, when compared to surrounding localities, and the presence of dunes meant that cultural materials might be exposed through wind erosion. However, close examination indicated that most of the debris on the island results from spoil disposal, and that even these rather recent depositions have been reworked by winds and storms. To evidence of cultural resources, either historic or prehistoric, was observed.

\section{SUMARY}

The area from Aransas Pass, Texas to North Harbor Island along the Tributary Channel of the Gulf Intracoastal Waterway was intensively surveyed during the first part of August, 1975. In this area, the Corps of Engineers is studying the feasibility of deepening and widening the tributary channel. No archaeological or historical remains were recognized in the surveyed area. This apparent lack of evidence does not mean there are absolutely no archaeological sites in the specified areas. The surrounding region has a large number of sites and it is certain that the area was heavily utilized in times past. It is possible that there are buried sites uncler the specific survey areas and that no evidence of these will be found until large-scale modifications are undertaken. It is also possible that there were sites previously on the localities but that these have been destroyed. Destruction of archaeological resources in the area has been ongoing for many years. In the past, natural forces such 
as hurricanes, tides, wind and associated erosion have caten away at archaeological remains. In more recent years, man has played a large part in the elimination of coastal archaeological and historical data. It is inevitable that utilization of the region will intensify and that more sites will be lost. An example is destruction of sites 41 SP 64 and 41 SP 78 before a complete scientific record could be obtained. Both sites were buried and were unknown to archaeologists until a combination of natural forces, construction, and vandalism caused their discovery and destruction.

\section{RECOMENDATIONS}

As a result of this survey, the following recommendations can be made:

(1) The proposed channel modifications and spoil disposal will not have any known direct impact on archaeological and historical resources in the locality. The area to be most severly affected by modifications has, in some parts, already been disturbed by previous construction. The undisturbed areas have no visible archaeological remains.

(2) If, during the course of channel modification, any unusual findings are seen in the spoil, work should be stopped and qualified archaeologists consulted before proceeding. It is impossible for archaeologists to be completely certain, from a surface survey, that all archaeological remnants have been located. In many instances they may lie deeply buried or completely 
hidden by heavy vegetation cover.

(3) Particular care should be taken in modifying North

Harbor Island. This locality may be the least

disturbed of all the survey areas and may possibly

hold buried archaeological resources.

\section{BIBLIOGRAPHY}

Blair, W. F.

1950 The Biotic Provinces of Texas. Texas Journal of Science $2(1): \quad 93-117$.

Briggs, A. K.

1971 Archeological Resources in the Texas Coastal Lowlands

and Littoral. Texas Historical Survey Committee and

Texas Water Development Board, Austin.

Campbe11, T. I.

1947 The Johnson Site: Type Site of the Aransas Focus of the Texas Coast. Bulletin of the Texas Archeological Society 18: 40-75.

1952 The Kent-Crane Site: A Shell Midden on the Texas Coast. Bulletin of the Texas Archeological Society 23: 39-77.

1958a Archeology of the Central and Southern Sections of the

Texas Coast. Bulletin of the Texas Archeological

Society 29: 145-175.

1958b Texas Archeology: A Guide to the Literature. Bulletin of the Texas Archeological Society 29: 145-175.

Corbin, J. E.

1963 Archeological Materials from the Northern Shore of 
Corpus Christi Bay, 'Texas. Bulletin of the Texas Archeological Society 34: 5-30.

1974 A Model for Cultural Succession for the Coastal Bend of Texas. Bulletin of the Texas Archeological Society 45: 29-54.

Dibble, D. S.

1972 An Assessment of the Archaeological Resources to be Affected by the Modification of the La Quinta Navigational Channel and Basin, (Corpus Christi Ship Channe1). Texas Archeological Salvage Project, Research Report 9 .

Dillehay, T. D.

1973 An Archeological Reconnaissance of Areas to be Affected by the Proposed Natural Gas Pipeline Company of Mmerica, Liquified Natural Gas Project, San Patricio County, Texas. Texas Archeological Salvage Project, Research Report 18.

Hester, T. R.

$1974 \Lambda$. Bibliographic Guide to the Archeology of Southern Texas. Journal of South Texas 1: 18-36. Corpus Christi.

Hester, T. R. and J. F. Corbin

1975 Two Burial Sites on the Central Texas Coast. Texas Journal of Science (in press).

McDonald, K. and D.S. Dibble

1973 An Archeological and Historical Resource Inventory and Evaluation of a Site in San Patricio County, Texas. 
Texas Archeological Survey, Research Report 33.

Story, D. A.

1968 Archeological Investigations at Two Central Texas Gulf Coast Sites. State Building Commission, Archoolagical Program, Report 13.

Suhm, D. A., et al.

1954 An Introductory Handbook of Texas Archeology. Bulletin of the Texas Archeological Society 25 (whole volume). 